Selected Papers from the European Commission CAST (CArbon-14 Source Term) Project-A Summary of the Main Results from the Final Symposium

(C) 2018 by the Arizona Board of Regents on behalf of the University of Arizona. This is an Open Access article, distributed under the terms of the Creative Commons Attribution licence (http://creativecommons. org/licenses/by/4.0/), which permits unrestricted reuse, distribution, and reproduction in any medium, provided the original work is properly cited.

\title{
PRELIMINARY ANALYSIS OF GASEOUS RADIOCARBON BEHAVIOR IN A GEOLOGICAL REPOSITORY HOSTED IN SALT ROCK
}

\author{
Riccardo Levizzari $^{1 *} \cdot$ Barbara Ferrucci $^{2} \cdot$ Alfredo Luce $^{1}$ \\ ${ }^{1}$ ENEA Saluggia Research Centre, Strada per Crescentino 41, 13040 Saluggia (VC), Italy. \\ ${ }^{2}$ ENEA Bologna Research Centre, Via Martiri di Monte Sole 4, 40129 Bologna (BO), Italy.
}

\begin{abstract}
A preliminary evaluation of gaseous radiocarbon $\left({ }^{14} \mathrm{C}\right)$ behavior under geological repository conditions for Italian radioactive high level waste-long-lived and intermediate level waste disposal has been performed. Although in Italy there is still no defined project for a geological disposal facility, current work may support future safety assessment studies for a hypothetical future repository in deep salt rock. In the Italian context of radioactive waste, the percentage of ${ }^{14} \mathrm{C}$ bearing waste to be disposed in a possible geological repository is low; irradiated graphite is the most important radiological source. Data about the radiological inventory has been collected to simulate production and migration of gaseous ${ }^{14} \mathrm{C}$ in a hypothetical geological repository. Three different conceptual models have been developed and simulated. The first model has considered a preliminary evaluation of the radiological impact referred to the whole inventory; the second and third model have evaluated the impact only due to the irradiated graphite. A preliminary sensitivity analysis has been carried out, highlighting the importance of geometry and of distribution coefficients $\left(\mathrm{K}_{\mathrm{d}}\right)$ in materials used to seal the disposal underground facility. Results show the possibility to correlate the $\mathrm{K}_{\mathrm{d}}$ values, the volume and the location of the sealing materials to the amount of ${ }^{14} \mathrm{C}$ migrating toward the surface.
\end{abstract}

KEYWORDS: geological repository, radioactive waste, radiocarbon, salt rock.

\section{INTRODUCTION}

The present work has been carried out within the EC CAST project (CArbon-14 Source Term), which aims to develop understanding of the generation and release of radiocarbon $\left({ }^{14} \mathrm{C}\right)$ from radioactive waste materials under conditions relevant to waste packaging and disposal in geological repositories. In the framework of different analyses supporting the long-term radiological safety of underground repositories, the migration of ${ }^{14} \mathrm{C}$ into the environment is a key issue. Radiocarbon has a relatively long half-life (5730 yr) and, depending on its speciation, a high mobility in the environment and a high efficiency of incorporation into the human body via the food-chain. During the post-closure phase in the life-cycle of a geological repository, significant quantities of ${ }^{14} \mathrm{C}$ labeled gases (i.e. methane and carbon dioxide) might be produced by corrosion of metals, irradiated graphite and by microbial degradation of organic waste; these chemical species might then be released from the disposal system and reach the biosphere in various ways. The understanding of the key mechanisms influencing ${ }^{14} \mathrm{C}$ transport from the repository to the surface is thus critical in this context and within the safety assessment of geological waste disposal. Therefore, it is important to gain new scientific understanding of different mechanisms dealing with the dynamics of radionuclides inside and outside future repositories.

In Italy, according to international practices, radioactive high level waste-long lived (HLW-LL) and intermediate level waste (ILW) are intended to be disposed of in an underground repository. In the meantime, until a site for underground disposal is selected, these waste products will be placed in a near surface repository for interim storage along with the final disposal of low level waste (LLW). The site for the interim storage has not been yet selected. The model simulations discussed here present a preliminary safety analysis of a hypothetical Italian geological repository hosted in salt

\footnotetext{
*Corresponding author. Email: riccardo.levizzari@enea.it.
} 
rock. In preparation for future assessment studies of post closure safety, the fate of gaseous ${ }^{14} \mathrm{C}$ in geological disposal conditions and its radiological relevance are analyzed. The first phase of this work has consisted in defining the radiological inventory of ${ }^{14} \mathrm{C}$ bearing radioactive waste (HLW-LL and ILW); in a second phase, the evaluation of the radiocarbon release and its dynamic in gaseous phase inside the repository has been evaluated. Three 3D models have been designed and evaluated; their main differences consist of the layout of the underground repository, of the type, features and volume of sealing materials and of the type and volume of waste disposed of. In particular, whereas in the former case, all the waste in the Italian inventory has been considered; in the latter two cases only the irradiated graphite waste (ILW) has been considered. Irradiated graphite generated from nuclear power plant dismantling has been a major issue in past nuclear research, due to various products of activation, including ${ }^{14} \mathrm{C}$ and tritium. These two radionuclides are critical in the context of the safety analysis for both underground and surface repositories, because they are a possible source of radioactive gaseous species. In fact, even today there are uncertainties related to many aspects of irradiated graphite management and disposal, as its interaction with the geochemical environment in which it is disposed, the distribution of the ${ }^{14} \mathrm{C}$ within the waste and the form in which the ${ }^{14} \mathrm{C}$ is released (i.e. organic, inorganic, liquid or gaseous). Some uncertainty also remains for the possible degradation of radioactive waste due to microbial activity in harsh conditions, caused by the absence of water, low porosity and high alkalinity induced by the cementitious near-field of a repository (Grant et al. 1997; Sorokin 2005). The behavior of ${ }^{14} \mathrm{C}$ for the final disposal of HLW and ILW has been analyzed in various geological formations, as for example for crystalline rocks by Poskas et al. (2016). They have considered the disposal of irradiated graphite in a deep geological repository, evaluating the ${ }^{14} \mathrm{C}$ transfer into the geosphere via the groundwater pathway. The speciation of the released ${ }^{14} \mathrm{C}$ into organic and inorganic species was taken into account. The role of backfill and sealing material in a geological repository is fundamental to retard the migration of radionuclides. Indeed, the hydraulic conductivity of the backfill material for organic ${ }^{14} \mathrm{C}$, and its distribution coefficient $\mathrm{K}_{\mathrm{d}}\left(\mathrm{m}^{3} / \mathrm{kg}\right)$ for inorganic ${ }^{14} \mathrm{C}$, that quantify the mass partitioning between the solid and the gaseous phase, represent the key parameters influencing the gaseous carbon flux into the geosphere.

\section{MATERIALS AND METHODS}

This work has been performed taking into account data of previous Italian studies on the management and disposal of radioactive waste (Luce et al. 2009) and data of the Italian radioactive waste inventory (Bove et al. 2009; Capone et al. 2011). The current inventory of Italian radioactive HLW-LL and ILW containing ${ }^{14} \mathrm{C}$ to be placed in a geological disposal is reported in Table 1 . The inventory does not include the residual waste from the reprocessing of irradiated fuel sent abroad (UK and France), to be returned to Italy as vitrified waste.

The conceptual models of the underground disposal facility have been designed by analogy with other existing geological repository projects (e.g. the U.S. Waste Isolation Pilot Plant, WIPP) (Nuclear Waste Partnership LLC 2016; Sevougian et al. 2016). The hypothetical underground facility was assumed to be located to a depth of about 800 meters, hosted in a salt body, $200 \mathrm{~m}$ thick, below clay rock about $700 \mathrm{~m}$ thick (Figure 1). A geological barrier is guaranteed by the salt rock, isolated from the surface by two different clay formations; the salt formation is considered quite homogeneous, although some discontinuities, as clay inclusions, cannot be excluded. Bentonite, concrete, asphalt and crushed salt have been used as sealing materials inside the underground facility.

The conceptual models of the waste-repository system have been elaborated considering the source of the ${ }^{14} \mathrm{C}$. The predominant percentage of ${ }^{14} \mathrm{C}$ in the inventory is related to irradiated 
graphite, which represents the most important radiological source in the context of Italian ${ }^{14} \mathrm{C}$ bearing radioactive waste. In nuclear power plants, where graphite is used as moderator of nuclear reactions, the production of ${ }^{14} \mathrm{C}$ is related to the activation of ${ }^{14} \mathrm{~N},{ }^{13} \mathrm{C}$, and ${ }^{17} \mathrm{O}$, which are the precursor species. The volume of graphite used in this study is referred to as untreated waste and is related to the decommissioning of the shutdown Italian MAGNOX nuclear reactor (Latina NPP).

Table 1 Inventory of Italian HLW-LL and ILW containing ${ }^{14} \mathrm{C}$.

\begin{tabular}{|c|c|c|c|}
\hline Origin & Materials & Volume $\left(\mathrm{m}^{3}\right)$ & $\begin{array}{l}\text { Inventory } \\
\text { of }{ }^{14} \mathrm{C}(\mathrm{GBq})\end{array}$ \\
\hline $\begin{array}{l}\text { GCR-Magnox reactor } \\
\text { (Latina NPP) }\end{array}$ & Graphite & $3.30 \mathrm{E} 03$ & $2.83 \mathrm{E} 04$ \\
\hline Nuclear power plants & Resins, metals & n.a. & $3.30 \mathrm{E} 03$ \\
\hline \multirow[t]{6}{*}{$\begin{array}{l}\text { Medical, industrial, } \\
\text { research }\end{array}$} & $\begin{array}{l}\text { Conditioned } \\
\text { sources }\end{array}$ & $172.60\left(863\right.$ drums $\left.200 \mathrm{dm}^{3}\right)$ & 0.42 \\
\hline & $\begin{array}{l}\text { Not treated } \\
\text { sources }\end{array}$ & $6.78\left(113\right.$ metallic drums $\left.60 \mathrm{dm}^{3}\right)$ & 92.80 \\
\hline & $\begin{array}{l}\text { Cemented } \\
\text { sources }\end{array}$ & $113.60\left(284\right.$ metallic drums $\left.400 \mathrm{dm}^{3}\right)$ & 106.28 \\
\hline & $\begin{array}{l}\text { Solid treated } \\
\text { sources }\end{array}$ & 42.00 (105 drums) & 11.00 \\
\hline & $\begin{array}{l}\text { Not treated } \\
\text { liquid waste }\end{array}$ & $\begin{array}{l}4.19\left(192 \text { plastic drums } 20 \mathrm{dm}^{3}\right. \\
2 \text { metallic drums } 120 \mathrm{dm}^{3} \\
\left.1 \text { metallic drum } 110 \mathrm{dm}^{3}\right)\end{array}$ & 4.05 \\
\hline & $\begin{array}{l}\text { Not treated } \\
\text { solid waste }\end{array}$ & $15.06\left(251\right.$ metallic drums $\left.60 \mathrm{dm}^{3}\right)$ & 2.36 \\
\hline
\end{tabular}

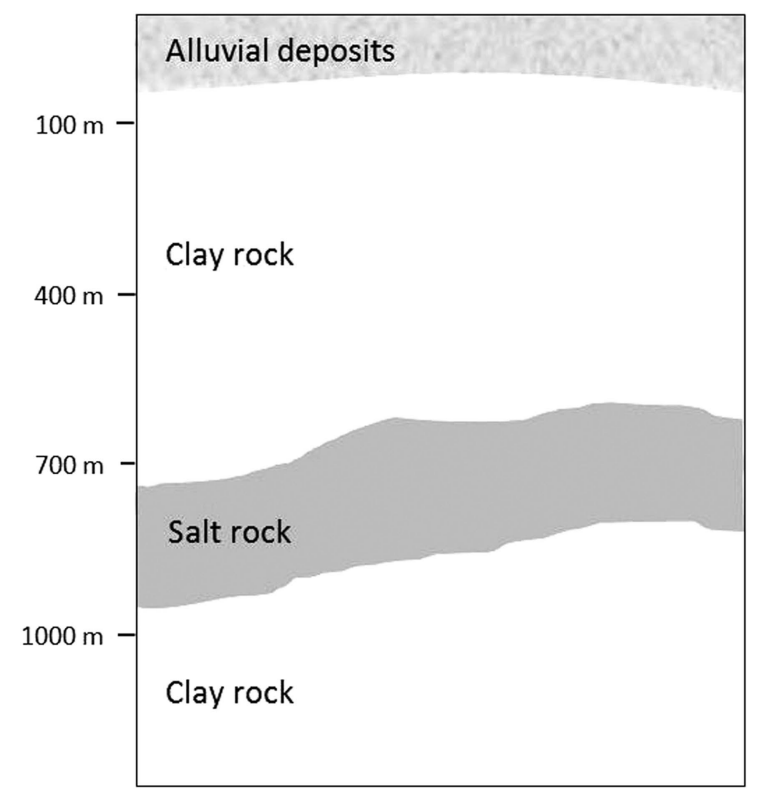

Figure 1 Geological stratigraphy of the host rock. 
The analysis about the release and migration of ${ }^{14} \mathrm{C}$ in near-field and far-field of a hypothetical geological repository has been carried out by means of numerical modeling, using the TOUGH2/EOS7R multi-phase code, with PetraSim software as the graphical interface (Oldenburg and Pruess 1995). In the transport modeling, the sorption of ${ }^{14} \mathrm{C}$ in the solid phase is taken into consideration through the distribution coefficient $\mathrm{K}_{\mathrm{d}}$. The objective of the modeling is to assess both the role of the layout and of the volume of different materials constituting the engineered barriers, and the importance of the $\mathrm{K}_{\mathrm{d}}$ coefficient in delaying the migration of ${ }^{14} \mathrm{C}$, released in the gaseous form from the waste. Although the $\mathrm{K}_{\mathrm{d}}$ parameter is a factor related to the partitioning of a radionuclide for the aqueous phase only, and there is no explicit distribution coefficient for the gas phase, in the TOUGH2 volatilization model, the retardation occurs for volatile species in the gas phase, just as it does in the aqueous phase, through the assumption that the gas phase consists primarily of air (Oldenburg and Pruess 1995).

To evaluate the dynamics of the gaseous radiocarbon in the repository, and to quantify its radiological relevance, three conceptual models have been developed, associated with two different 3D layouts. The first one, referred to a 3D multi-room model (MR), represents a whole system containing all the waste inventory listed in Table 1; three different cases have been simulated (MR1, MR2, MR3) using different volumes of bentonite to seal the underground repository. The latter two conceptual models describe systems containing only the irradiated graphite and are referred to as a 3D single-room model with conservative approach (SRC) and with realistic approach (SRR). In the SRC model four different cases have been simulated (SRC1, SRC2, SRC3, SRC4) using different $\mathrm{K}_{\mathrm{d}}$ values for sealing materials; in the SRR model only one case has been simulated. All the models include a single shaft that connects the underground repository to the ground surface. No assumption has been made about the ${ }^{14} \mathrm{C}$ speciation. For what concern the emission from graphite, an important fraction of the ${ }^{14} \mathrm{C}$ is not releasable, because it is strongly bounded to the graphite matrix. Moreover, the total fraction and the fraction of each gaseous species (mainly $\mathrm{CO}_{2}$ and $\mathrm{CH}_{4}$ ) that migrates outside the waste, depend on the history of graphite (i.e. irradiation history, operational conditions, etc.) (Toulhoat et al. 2018); but due to the lack of information about the Italian graphite inventory, these data are not currently available and conservative assumptions will be used in the simulations.

Since at the moment some aspects of the complex processes simulated in disposal rooms are not known, the elaboration of the conceptual models has been performed with an arbitrary set of conservative assumptions. This approach to conservative parametrization supports aspects of sealing performance studies. Salt formations are favorable rocks to host a geological disposal because they maintain unsaturated conditions; however, salt formations might not be considered completely dry because of the presence of water/humidity related to repository operations and especially because of the presence of brine, that might move from the hosting rock to the excavated zone due to pressure gradient, thermal gradient or rock stress gradient (Rübel et al. 2013; Sandia National Laboratories 2013). This condition, combined with the possible assumption of complete saturation with brine of the disturbed rock zone close to the underground excavation, results in a possible water flow into the repository (Sandia National Laboratories 2006). In this work, a conservative approach has been adopted and the most unfavorable repository conditions have been assumed, considering a constant brine flow into the storage rooms, which can cause the corrosion of carbon steel waste packages and the leaching of ${ }^{14} \mathrm{C}$ from waste. It is assumed that no overpack is provided to contain drums and, in each room, waste is considered as compacted volume. No convergence phenomenon of the host rock has been considered. In all three models, the evolution of described arbitrary scenario has been modeled with two main time steps: the first, from 0 to $300 \mathrm{yr}$ after repository closure, when 

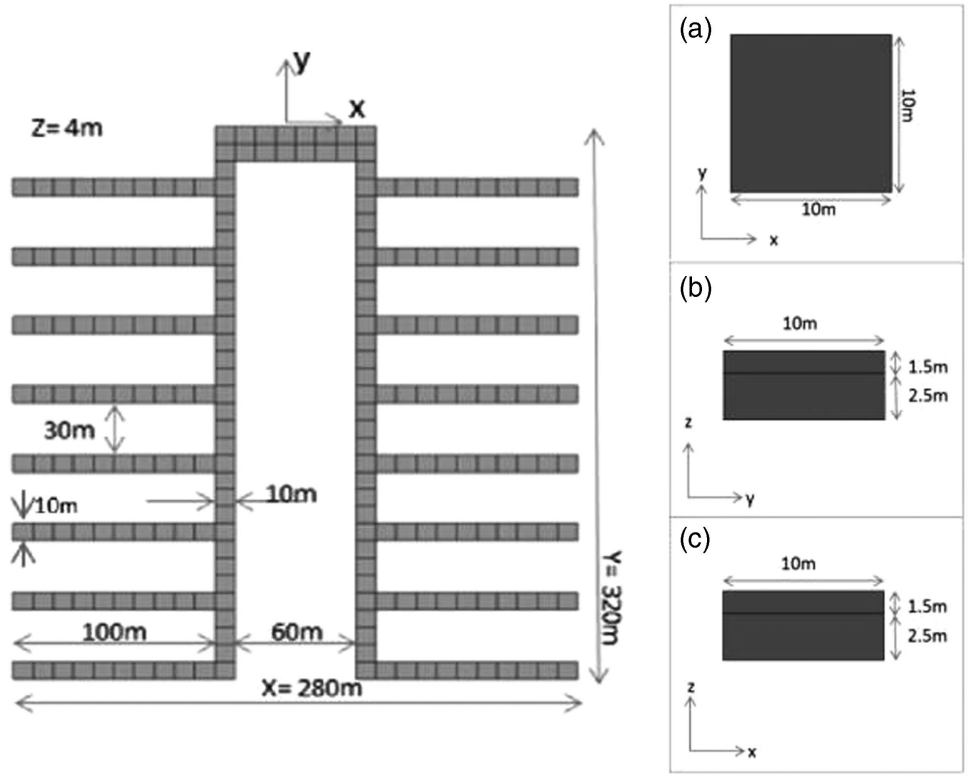

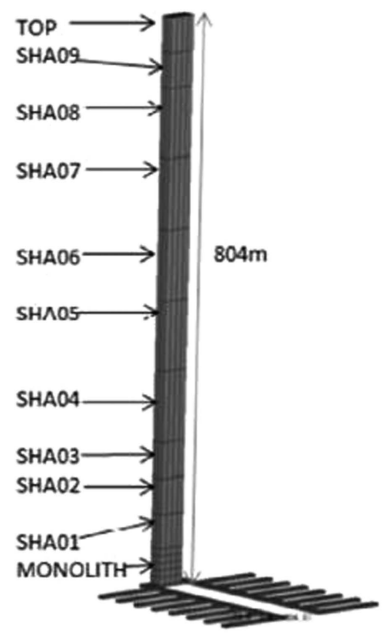

Figure 2 Multi-room conceptual model.

no release of radionuclides occurs and waste package integrity is maintained (Sullivan 2004); the second, from $300 \mathrm{yr}$ to $300,000 \mathrm{yr}$ after the repository closure, when steady-state conditions are established, waste packages corrosion and ${ }^{14} \mathrm{C}$ release take place, due to the presence of brine and water inside the repository.

The main purpose of the MR model has been to test the performance of the barrier system in delaying the migration of gaseous ${ }^{14} \mathrm{C}$, by considering different layouts and volumes of the sealing materials at the repository level. The layout has been designed on the basis of the WIPP project (WIPP 2009). It consists of 16 rooms arranged in two panels, separated by a central pillar of intact salt and connected to the ground surface by a single shaft (Figure 2).

The engineered barrier system includes four materials that completely fill and seal the shaft, rooms and drifts. No disturbed rock zone has been included in this conceptual model; the base of the shaft, after repository closure, consists of a monolith of concrete, $50 \mathrm{~m}$ high, $10 \mathrm{~m}$ long, and $10 \mathrm{~m}$ thick. In each storage rooms, the total amount of the estimated ${ }^{14} \mathrm{C}$ activity is assumed equally distributed within the volume of the waste. The simulations start from a steady-state initial condition calculated assuming an initial pressure of $15 \mathrm{MPa}$ (lithostatic pressure) at the repository level (Kristopher 2014). This is a conservative assumption that implies, immediately after the repository closure, a lithostatic pressure in the storage room. During all the computation time, this conditon, assuming a constant gas production within the storage rooms, generates a pressure profile that provides a gas flow from the underground repository to the top of the shaft. In this scenario only migration by diffusion has been modeled. The source term is modeled as a gaseous emission of ${ }^{14} \mathrm{C}$ with a release rate of $10 \%$ per year of the total activity; this highly conservative and unrealistic release rate has been intended to force the model to produce results that bring out the effects of different features of the sealing materials on the ${ }^{14} \mathrm{C}$ migration. In order to make a preliminary sensitivity analysis, the volume of bentonite has been selected as the focus of the sensitivity analysis, because of its very low permeability and its 

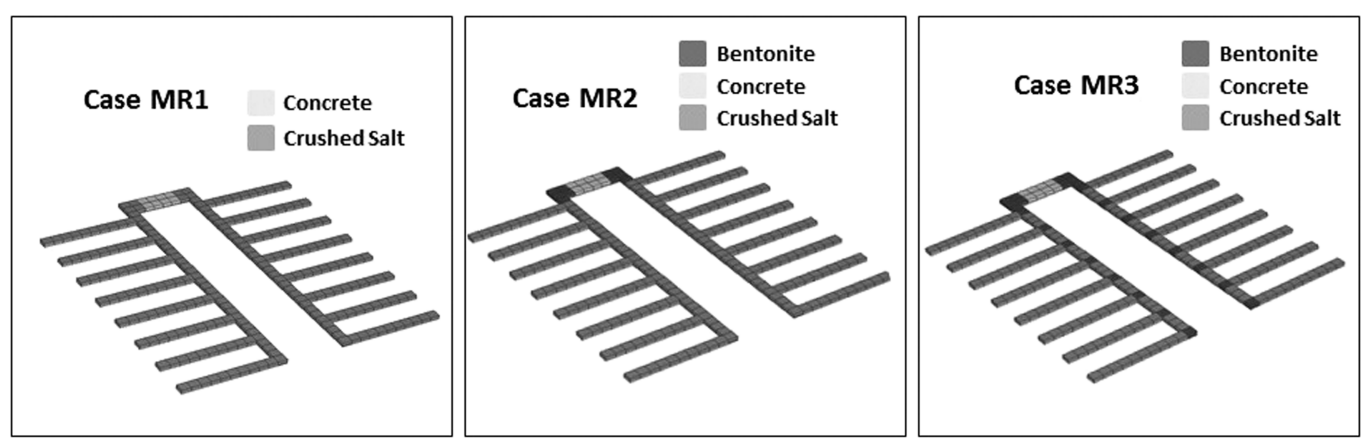

Figure 3 Sealing materials configuration in the MR model.

capacity to retard most radionuclides by sorption (Daeman and Ran 1997). Three case studies have been developed; in MR1 case, no bentonite is used to seal the underground facility; in MR2 case, a bentonite volume of $3657 \mathrm{~m}^{3}$ is placed around the lower part of the monolith (underground shaft closure); in MR3 case, a bentonite volume of $9508 \mathrm{~m}^{3}$ is distributed along the entrance of every disposal room and around the base of the monolith (Figure 3).

In these cases, generic features have been used for the sealing materials. According to Yim and Caron (2006), a $\mathrm{K}_{\mathrm{d}}$ value of $1.0 \mathrm{E}-5 \mathrm{~m}^{3} / \mathrm{kg}$ has been assumed for asphalt, waste form and concrete monolith, while $\mathrm{K}_{\mathrm{d}}=0$ for the crushed salt and intact salt; because of its sorption capacity, a high $\mathrm{K}_{\mathrm{d}}$ value $\left(1 \mathrm{~m}^{3} / \mathrm{kg}\right.$ ) for bentonite has been assumed (Daeman and Ran 1997). The layout of shaft sealing materials has been maintained constant in all cases (Figure 4).

In the SRC model, a new barrier system configuration has been taken into account, based on Freeze et al. (2013), and only irradiated graphite is considered. Only one storage room has been considered, containing 196 hypothetical waste packages, each with a volume of $1 \mathrm{~m}^{3}$. All the activity of ${ }^{14} \mathrm{C}$ related to the irradiated graphite is assumed equally distributed throughout these packages. Crushed salt, waste form and shaft seal materials constitute the repository barrier system. A disturbed rock zone, $10 \mathrm{~m}$ thick, has been modeled as volume of rock, surrounding the excavated zone, that experiences durable changes in hydraulic parameters, as porosity and permeability (Freeze et al. 2013). The source term is modeled as a gaseous emission of ${ }^{14} \mathrm{C}$, characterized by a constant release rate of $0.0067 \%$ per year of the total ${ }^{14} \mathrm{C}$ activity contained in graphite (Fugaru 2018). Where not specified in the following description, input data assumed for the simulations are the same assumed for the MR model. Figure 5 illustrates the configuration of materials featuring the shaft sealing, as defined for a generic vertical shaft in US WIPP, that consist of concrete, asphalt, salt and bentonite, to enhance physical and chemical barrier to radionuclide migration. The values of their main parameters are reported in Table 2 . A small inverse Henry's constant has been assigned, such that gaseous ${ }^{14} \mathrm{C}$ mostly volatilizes leading to a worst case scenario (Oldenburg and Pruess 1995). Four main cases have been simulated (SRC1, SRC2, SRC3, SRC4), starting from the most conservative assumption (SRC1) in which, for all the sealing materials, the $\mathrm{K}_{\mathrm{d}}$ value is 0 . In the other three cases, a $\mathrm{K}_{\mathrm{d}}$ value of $1.0 \mathrm{E}-5\left(\mathrm{~m}^{3} / \mathrm{kg}\right)$ has been assumed for the waste form, the bentonite, the concrete and the asphalt (Table 3).

The SRR model has been developed in analogy with the previous one. To evaluate the radiological impact of ${ }^{14} \mathrm{C}$ in a more realistic way, a less conservative approach has been assumed by using a $\mathrm{K}_{\mathrm{d}}>0$ for all sealing materials (Table 3). The main features of the previous conceptual 


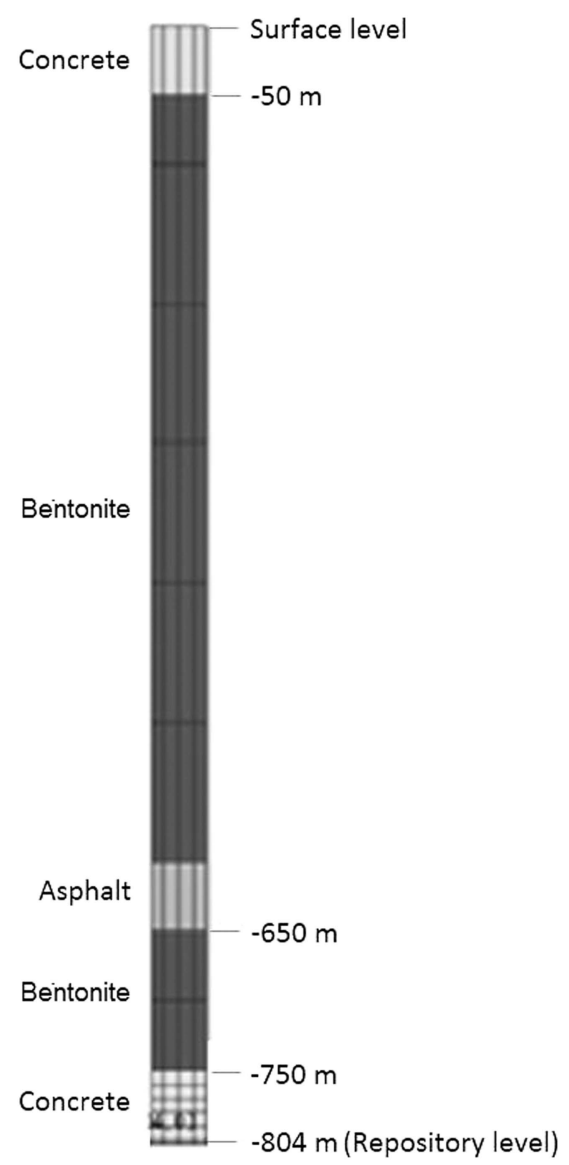

Figure 4 Sealing materials for the shaft in the MR model.

model have been preserved. In this simulation, the release of ${ }^{14} \mathrm{C}$ from the irradiated graphite has been analysed with a more detailed approach. According to Doulgeris et al. (2015), two main dynamics featuring the behavior of ${ }^{14} \mathrm{C}$ have been considered; first, the $\mathrm{CO}_{2}$ and $\mathrm{CH}_{4}$ released from graphite are partitioned between the solution and the gas phase, according to the Henry's law. The second is related to the contribution of cementitious materials in attenuating ${ }^{14} \mathrm{C}$ migration, because of $\mathrm{CO}_{2}$ carbonation; in fact, as highlighted by Poskas et al. (2016), encapsulation of graphite inside a container with cementitious material would decrease the maximum flux of inorganic ${ }^{14} \mathrm{C}$ into the geosphere, by approximately one order of magnitude. Methane is the predominant form of gaseous ${ }^{14} \mathrm{C}$ considered for this case, with no adsorption capacity into the salt rock formation $\left(\mathrm{K}_{\mathrm{d}}=0 \mathrm{~m}^{3} / \mathrm{kg}\right)$. A congruent release of gaseous ${ }^{14} \mathrm{C}$ starts $300 \mathrm{yr}$ after the repository closure, with a release rate of $0.0067 \%$ per year, as gaseous ${ }^{14} \mathrm{CH}_{4}$ (Fugaru 2018). Migration is assumed to take place only by diffusion.

\section{RESULTS AND DISCUSSION}

The ${ }^{14} \mathrm{C}$ amount was calculated for two specific blocks common to the three models: near the compacted hearten fill at the top of the shaft, and near the concrete monolith at the base of the shaft. 


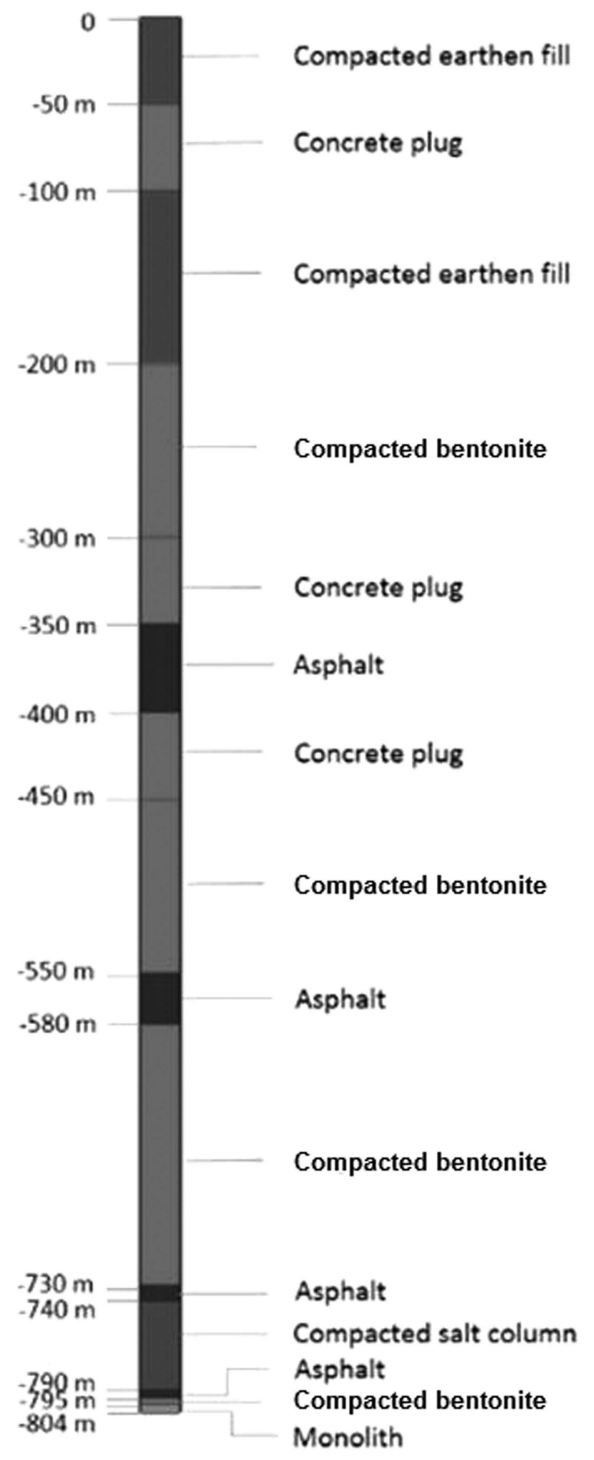

Figure 5 Sealing materials for the shaft in the SR model.

The results of the multi-room and single-room models are not comparable, because of the different discretization and conceptualization of the models; therefore, the data are reported in different graphs. The simulation results of the MR model, cases MR1 and MR2, show that, at the base of the shaft in the monolith, the presence of a bentonite volume of about $3600 \mathrm{~m}^{3}$ leads to a decrease of $3 \%$ of the cumulative amount of ${ }^{14} \mathrm{C}$. Increasing the bentonite volume of about three times, from case MR2 to case MR3, the amount of ${ }^{14} \mathrm{C}$ decreases of 23.5\%, from 2.3E10 Bq to 5.3E09 Bq (Figure 6).

In all three cases, due to the large volume of bentonite (about $4.0 \mathrm{E} 05 \mathrm{~m}^{3}$ ) and due to the other sealing materials in the shaft, the maximum cumulative amount of ${ }^{14} \mathrm{C}$ at the top of the shaft is 
Table 2 Values of main parameters of the sealing materials used in the simulations.

\section{Gaseous ${ }^{14} \mathrm{C}$ parameters}

Diffusion coefficient in gas phase $\left(\mathrm{m}^{2} / \mathrm{s}\right)$

Diffusion coefficient in liquid phase $\left(\mathrm{m}^{2} / \mathrm{s}\right)$

Inverse Henry's Constant (1/Pa)

Hydraulic parameters

Concrete/monolith

Bentonite

Crushed salt

Asphalt

Intact salt

Disturbed rock zone

Waste

Earthen
1.3E-4 (Quintessa Ltd. \& Geofirma Engineering Ltd. 2011)

4.9E-11 (Quintessa Ltd. \& Geofirma Engineering Ltd. 2011)

3.0E-10 (Quintessa Ltd. \& Geofirma Engineering Ltd. 2011)

Permeability $\left(\mathrm{m}^{2}\right)$

1.0E-19 (Enssle et al. 2014)

$1.0 \mathrm{E}-19$ (WIPP 2009)

1.0E-18 (Mariner et al. 2015)

1.0E-20 (WIPP 2009)

1.0E-23 (WIPP 2009)

1.1E-16 (Sandia National Laboratories 2013)

1.0E-13 (Mariner et al. 2015)

1.0E-14 (WIPP 2009)
Porosity (-)

0.250 (Enssle et al. 2014)

0.290 (Enssle et al. 2014)

0.113 (Mariner et al. 2015)

0.010 (WIPP 2009)

0.018 (WIPP 2009)

0.013 (Mariner et al. 2015)

0.300 (Mariner et al. 2015)

0.300 (WIPP 2009) 
Table $3 \quad \mathrm{~K}_{\mathrm{d}}\left(\mathrm{m}^{3} / \mathrm{kg}\right)$ values of the sealing materials used in the simulations.

\begin{tabular}{|c|c|c|c|c|c|c|}
\hline & $\begin{array}{l}\mathrm{K}_{\mathrm{d}_{-1} 14 \mathrm{C}} \\
(\mathrm{MR} 1,2,3)\end{array}$ & $\begin{array}{l}\mathrm{K}_{\mathrm{d} \_14 \mathrm{C}} \\
(\mathrm{SRC} 1)\end{array}$ & $\begin{array}{l}\mathrm{K}_{\mathrm{d}_{-} 14 \mathrm{C}} \\
(\mathrm{SRC2})\end{array}$ & $\begin{array}{l}\mathrm{K}_{\mathrm{d} \_14 \mathrm{C}} \\
(\mathrm{SRC})\end{array}$ & $\begin{array}{l}\mathrm{K}_{\mathrm{d} \_14 \mathrm{C}} \\
(\mathrm{SRC} 4)\end{array}$ & $\begin{array}{l}\mathrm{K}_{\mathrm{d}_{1} 14 \mathrm{C}} \\
(\mathrm{SRR})\end{array}$ \\
\hline Concrete monolith & $\begin{array}{l}1.0 \mathrm{E}-05 \\
\text { (Yim \& C. 2006) }\end{array}$ & 0 & 0 & $\begin{array}{l}1.0 \mathrm{E}-05 \\
\text { (Yim \& C. 2006) }\end{array}$ & 0 & $\begin{array}{l}0.5 \\
\text { (Enssle et al. 2014) }\end{array}$ \\
\hline Bentonite & $\begin{array}{l}1.0 \\
\text { (Daeman \& R. 1997) }\end{array}$ & 0 & $\begin{array}{l}\text { 1.0E-05 } \\
\text { (Yim \& C. 2006) }\end{array}$ & 0 & 0 & $\begin{array}{l}1.9 \mathrm{E}-02 \\
\text { (Wersin et al. 2014) }\end{array}$ \\
\hline Crushed salt & 0 & 0 & 0 & 0 & 0 & 0 \\
\hline Asphalt & $\begin{array}{l}1.0 \mathrm{E}-05 \\
\text { (Yim \& C. 2006) }\end{array}$ & 0 & 0 & 0 & $\begin{array}{l}\text { 1.0E-05 } \\
\text { (Yim \& C. 2006) }\end{array}$ & $\begin{array}{l}1.0 \mathrm{E}-05 \\
\text { (Yim \& C. 2006) }\end{array}$ \\
\hline Intact salt & 0 & 0 & 0 & 0 & 0 & 0 \\
\hline Disturbed rock zone & 0 & 0 & 0 & 0 & 0 & 0 \\
\hline Waste & $\begin{array}{l}1.0 \mathrm{E}-05 \\
\text { (Yim \& C. 2006) }\end{array}$ & 0 & 0 & 0 & 0 & $\begin{array}{l}1.0 \mathrm{E}-05 \\
\text { (Yim \& C. 2006) }\end{array}$ \\
\hline Earthen & $\begin{array}{l}1.0 \mathrm{E}-05 \\
\text { (Yim \& C. 2006) }\end{array}$ & 0 & 0 & 0 & 0 & $\begin{array}{l}1.0 \mathrm{E}-05 \\
\text { (Yim \& C. 2006) }\end{array}$ \\
\hline
\end{tabular}


orders of magnitude lower than in the monolith at the base of the shaft (about 2.3E-1 Bq in the case MR1, about 1.4E-2 Bq in the case MR2 and about 2.0E-3 Bq in the case MR3) (Figure 7).

The simulation results of the SRC model (cases SRC1, SRC2, SRC3, SRC4) show that sealing materials with values of $\mathrm{K}_{\mathrm{d}}$ lower than $1.0 \mathrm{E}-5 \mathrm{~m}^{3} / \mathrm{kg}$ do not affect the cumulative amount of the gaseous ${ }^{14} \mathrm{C}$, with quite similar results in all the four cases. The peak of ${ }^{14} \mathrm{C}$ amount at the top of the shaft occurs at about $4000 \mathrm{yr}$ after the repository closure, with a maximum value of 2.7E03 Bq. After $300,000 \mathrm{yr}$, the ${ }^{14} \mathrm{C}$ amount at the top of the shaft becomes negligible in all the simulated cases, decreasing to a minimum value of about $1.0 \mathrm{E}-15 \mathrm{~Bq}$. The peak of the ${ }^{14} \mathrm{C}$

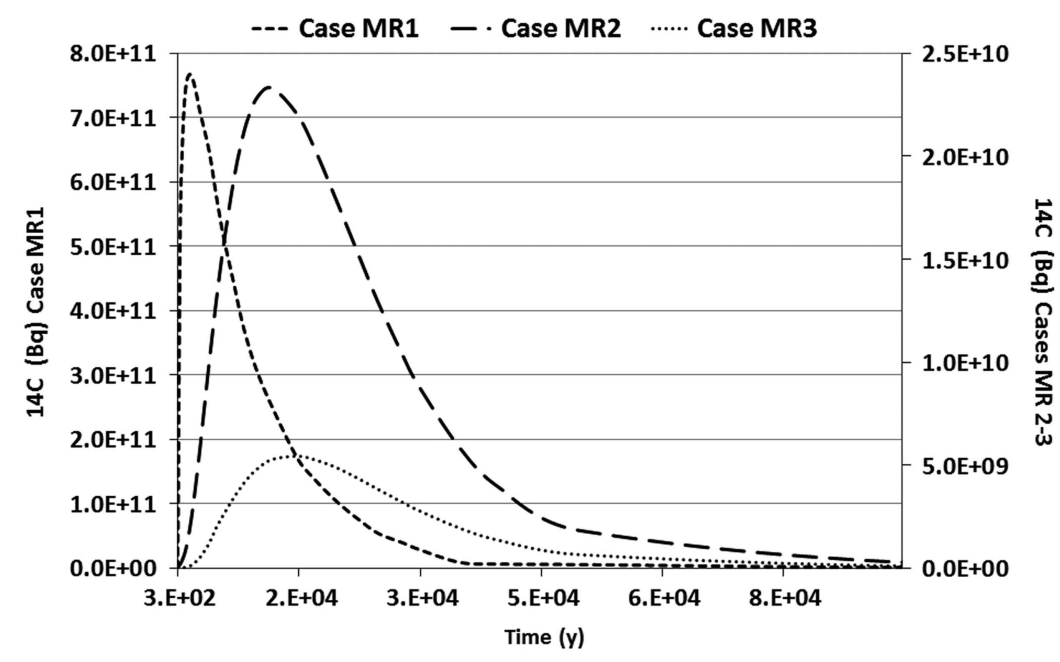

Figure 6 Cumulative amount of ${ }^{14} \mathrm{C}$ in the monolith at the base of the shaft (MR model).

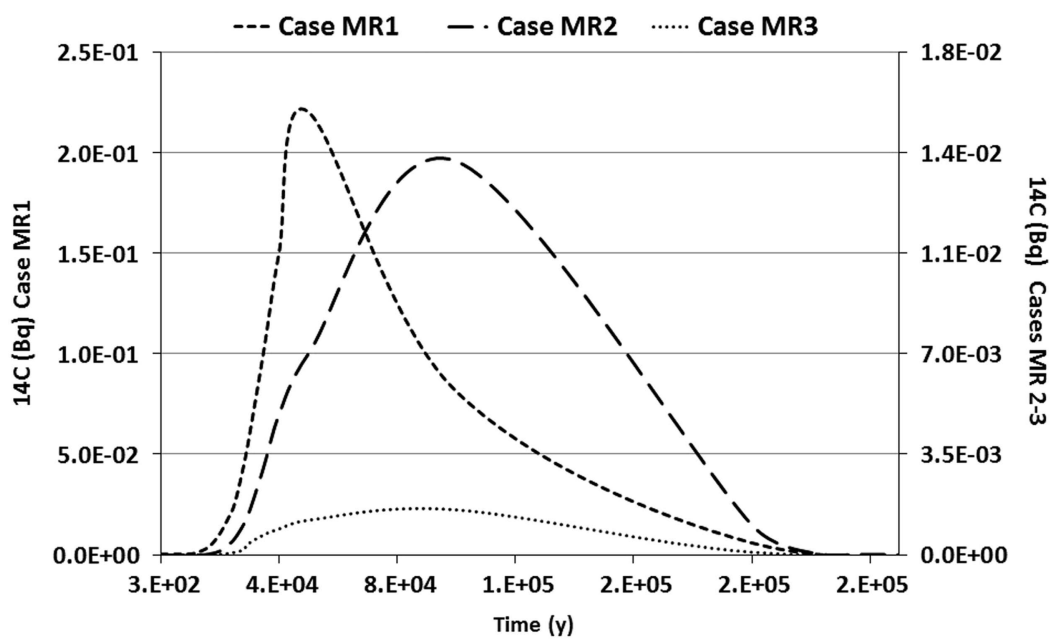

Figure 7 Cumulative amount of ${ }^{14} \mathrm{C}$ at the top of the shaft (MR model). 


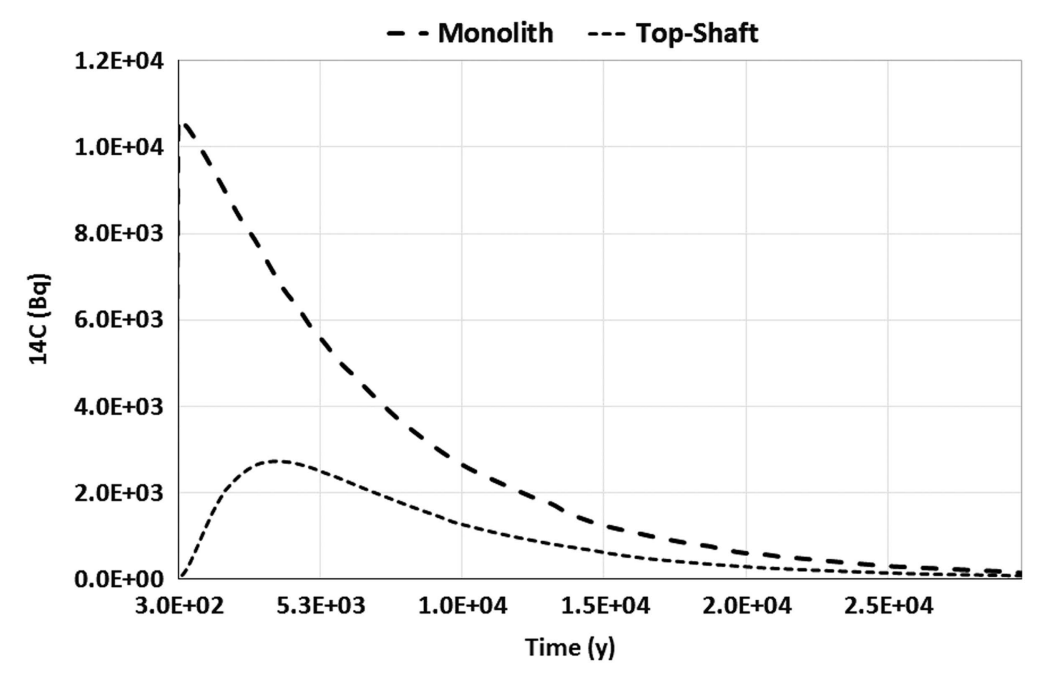

Figure 8 Cumulative amount of ${ }^{14} \mathrm{C}$ ( $\mathrm{SRCl}$ case, representative of the four cases simulated).

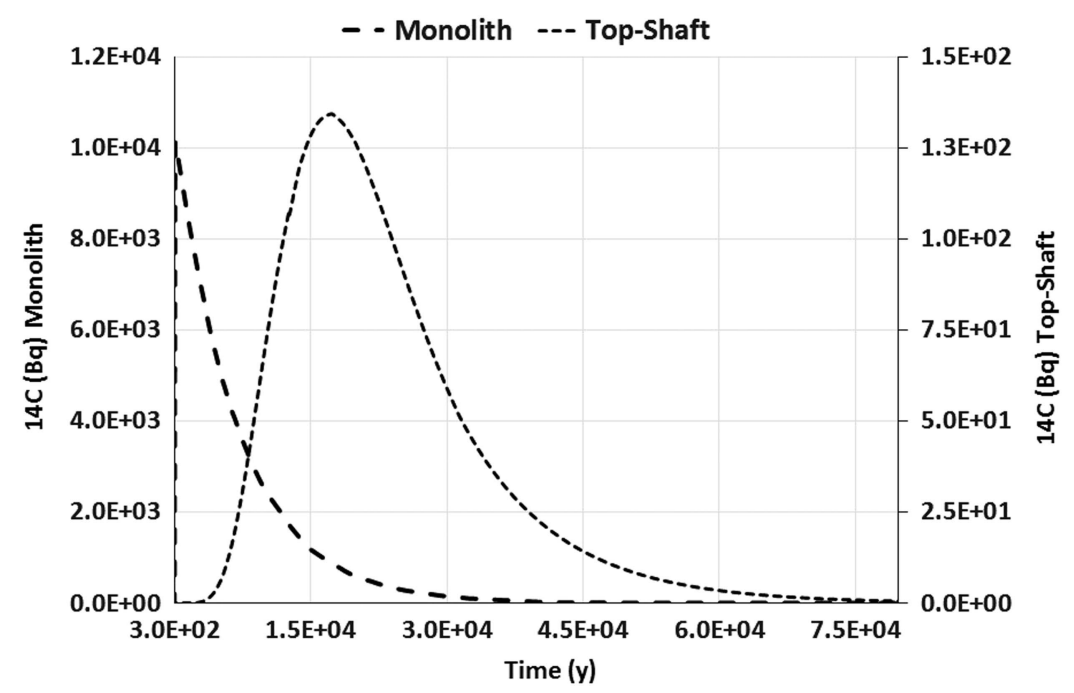

Figure 9 Cumulative amount of ${ }^{14} \mathrm{C}$ (SRR model).

gaseous emission in the monolith at the base of the shaft occurs about $400 \mathrm{yr}$ after the repository closure with value of about 1.0E04 Bq (Figure 8).

In the SRR model, the peak of the ${ }^{14} \mathrm{C}$ gaseous emission at the top of the shaft, occurs about $17,000 \mathrm{yr}$ after the repository closure with about 1.4E02 Bq. Also in this case, the peak of the ${ }^{14} \mathrm{C}$ gaseous emission in the monolith occurs about $400 \mathrm{yr}$ after the repository closure with value of 1.0E04 Bq (Figure 9). 


\section{CONCLUSION}

The paper reports a preliminary analysis of the radiological impact of gaseous ${ }^{14} \mathrm{C}$ from HLWLL and ILW disposed in a hypothetical Italian geological repository hosted in salt rock. Before this work, no safety assessment or generic safety studies had been developed in the Italian context for geological disposal. The three conceptualizations of the underground facility, and the following simulations, have improved the knowledge about the future safety issues that will have to be discussed for final disposal of Italian HLW-LL and ILW. The results of the MR model confirm that the capacity of materials to retard radionuclides migration depends on their $\mathrm{K}_{\mathrm{d}}$ value and their volume in the repository. High values of $\mathrm{K}_{\mathrm{d}}$ significantly affect the barrier system performances. From detailed analysis of the simulation results of the MR model, taking into account the cases 2 and 3, it is evident that, for high values of $K_{d}$, the performance of the sealing materials is proportional to their volume and density. Increasing the total volume of the bentonite by about three times, moving from the case 2 to the case 3 , the cumulative amount of ${ }^{14} \mathrm{C}$ in the monolith is reduced of about one order of magnitude (from 2.3E10 Bq to 5.3E09 Bq). At the top of the shaft, in all three cases, the significant decrease of the cumulative amount of ${ }^{14} \mathrm{C}$, with respect to the monolith, depends mainly on the large volume of bentonite and of the other sealing materials in the shaft. In the SRC and SRR conceptual models, a more realistic scenario than the MR model has been simulated. In particular, in SRR model a release rate of $0.0067 \%$ per year and $a K_{d}>0$ for all the sealing materials have been assumed. The maximum value of the cumulative amount of ${ }^{14} \mathrm{C}$ calculated in the SRR model at the top of the shaft $(1.4 \mathrm{E} 02 \mathrm{~Bq})$ is about one order of magnitude lower than the cumulative amount calculated in the cases of the SRC model (2.7E03 Bq).

The results of this study show that, if disposed in a hypothetical geological repository hosted in salt rock, a low radiological impact of ${ }^{14} \mathrm{C}$ from the Italian graphite waste and other HLW-LL and ILW can be expected. The mitigation of ${ }^{14} \mathrm{C}$ migration towards the surface, and the following reduction of the radiological impact, are related to the combined actions of the low conductivity of salt host rock, of the adsorbing capacity of sealing materials and of the radioactive decay. Moreover, the conservative assumptions used in the various simulations (i.e. saturation with brine for all the calculation time, relatively high permeability of the disturbed rock zone and backfill around the waste packages, etc.) might have produced overstated values of ${ }^{14} \mathrm{C}$ at the top of the shaft.

\section{REFERENCES}

Bove R, Capone M, Cherubini N, Compagno A, Dodaro A, Marlia A. 2009. Revisione critica dell'inventario nazionale dei rifiuti radioattivi ai fini dello smaltimento-Anno 2009. Rome: ENEAMinistero dello Sviluppo Economico. In Italian.

Capone M, Cherubini N, Dodaro A, Falconi L. 2011. Revisione critica dell'inventario nazionale dei rifiuti radioattivi ai fini dello smaltimento-Anno 2011. Rome: ENEA-Ministero dello Sviluppo Economico. In Italian.

Daeman J, Ran C. 1997. Bentonite as a waste isolation pilot plant shaft sealing material. Sandia Report SAND96-1968. Albuquerque (NM): Sandia National Laboratories.

Doulgeris C, Humphreys P, Rout S. 2015. An approach to modelling the impact of ${ }^{14} \mathrm{C}$ release from reactor graphite in a geological disposal facility. Mineralogical Magazine 79(6):1495-503.
Enssle CP, Brommundt J, Kaempfer TU, Mayer G, Wendling J. 2014. Full-scale 3D modelling of a nuclear waste repository in the CallovioOxfordian clay. In: Norris B, Bruno J, editors. Clays in Natural and Engineered Barriers for Radioactive Waste Confinement. London: Geological Society. Special Publications 400. p 469-81.

Freeze G, Gardner WP, Vaughn P, Sevougian SD, Mariner P, Mousseau V, Hammond G. 2013. Enhancements to generic disposal system modeling capabilities. Sandia Report SAND2013-10532P. Albuquerque (NM): Sandia National Laboratories.

Fugaru V. 2018. Report on the release of C-14 from irradiated VVR-S graphite to solution and gas phase. CAST Project Report D5.14. Available at https://www.projectcast.eu/

Grant WD, Holtom GJ, Rosevear A, Widdowson D. 1997. A Review of environmental microbiology 
relevant to the disposal of radioactive waste in a deep underground repository. UK Nirex Report NSS R329. Harwell, Didcot, Oxfordshire, UK.

Kristopher LK. 2014. Summary results for brine migration. Modeling performed by LANL, LBNL, and SNL for the UFD Program. Sandia Report SAND2014-18217R. Albuquerque (NM): Sandia National Laboratories.

Luce A, Mura A, Taglioni A, Zarlenga F. 2009. Le attività condotte dall'ENEA fra il 1996 e il 2003 per il sito nazionale di deposito dei rifiuti radioattivi. Rome: ENEA-Ministero dello Sviluppo Economico. In Italian.

Mariner PE, Gardner WP, Hammond GE, Sevougian ER. 2015. Application of generic disposal system models. Sandia Report SAND2015-10037 R; FCRD-UFD2015-000126. Albuquerque (NM): Sandia National Laboratories.

Nuclear Waste Partnership LLC. 2016. Waste Isolation Pilot Plant. Documented Safety Analysis. DOE/WIPP 07-3372, Rev 5b. Carlsbad (NM): U.S. Department of Energy Field Office.

Oldenburg CM, Pruess K. 1995. EOS7R: Radionuclide Transport for TOUGH2. Report LBL-34868. Lawrence Berkeley National Laboratory. Berkeley: University of California.

Poskas P, Grigaliuniene D, Narkuniene A, Kilda R, Justinavicius D. 2016. Modeling of irradiated graphite ${ }^{14} \mathrm{C}$ transfer through engineered barriers of a generic geological repository in crystalline rocks. Science of the Total Environment 569:1126-35.

Quintessa Ltd. and Geofirma Engineering Ltd. 2011. OPG's Deep geologic repository for low and intermediate level waste. Postclosure Safety Assessment. Quintessa Ltd and Geofirma Engineering Ltd Report NWMO DGR-TR-2011-32 for the Nuclear Waste Management Organization. Toronto.

Rübel A, Buhmann D, Meleshyn A, Mönig J, Spiessl S. 2013. Aspects on the gas generation and migration in repositories for high level waste in salt formations. Gesellschaft für Anlagen-und Reaktorsicherheit (GRS) mbH Report 203. Germany.

Sandia National Laboratories. 2006. WIPP room evolution and performance assessment implications. Sandia Report SAND2013-10532P.
Albuquerque: Sandia National Laboratories. Procedeeings from the 41st U.S. Symposium on Rock Mechanics (USRMS): 50 years of rock mechanics - Landmarks and future challenges, June 17-21 2006, Golden, Colorado.

Sandia National Laboratories. 2013. Enhancements to generic disposal system modeling capabilities. Sandia Report SAND2013-10532P. Albuquerque (NM): Sandia National Laboratories.

Sevougian DS, Stein ER, Ham GE. 2016. Enhanced performance assessment models for generic deep geologic repositories for High-Level Waste and Spent Nuclear Fuel. Procedeeings from Waste Management Conference (WM2016). March 6-10, 2016, Phoenix. Tempe (AZ): Waste Management Symposia, Inc. p 5095-115.

Sorokin DY. 2005. Is there a limit for high-pH life? International Journal of Systematic and Evolutionary Microbiology 55(4):1405-6.

Sullivan T. 2004. Waste Container and Waste Package Performance Modeling to Support Safety Assessment of Low and Intermediate-Level Radioactive Waste Disposal. BNL-74700-2005-IR. Environmental Sciences Department - Environmental Research \& Technology Division, Brookhaven National Laboratory.

Toulhoat N, Moncoffre N, Narkunas E, Poskas P, Bucur C, Ichim C. 2018. Final report on results from Work Package $5:{ }^{14} \mathrm{C}$ in irradiated graphite. CAST Project Report D5.19. Available at https:// www.projectcast.eu/

Wersin P, Kiczka M, Rosch D. 2014. Safety case for the disposal of spent nuclear fuel at Olkiluoto Radionuclide solubility limits and migration parameters for the canister and buffer. Posiva Report 2012-39. Eurajoki, Finland.

WIPP. 2009. Material specification. Shaft sealing system. Compliance submittal design report. Waste isolation pilot plant. Hazardous waste facility. Permit renewal application, September 2009. Available at http://www.wipp. energy.gov

Yim M, Caron F. 2006. Life cycle and management of ${ }^{14} \mathrm{C}$ from nuclear power generation. Progress in Nuclear Energy 48:2-36. 